\title{
Gamification and Game-Based Learning: Two Strategies for the
}

\section{1 st Century Learner}

\author{
Jorge F. Figueroa-Flores ${ }^{1 *}$ \\ ${ }^{1}$ School of Social and Human Sciences, Universidad del Este, Carolina, Puerto Rico \\ *Jorge F. Figueroa-Flores, E-mail: jffigueroa@suagm.edu
}

Received: September 22, 2016 Accepted: October 12, 2016 Online Published: November 14, 2016

doi:10.22158/wjer.v3n2p507 URL: http://dx.doi.org/10.22158/wjer.v3n2p507

\begin{abstract}
The use of emergent technologies in education has evolved tremendously since the $21^{\text {st }}$ century. For plenty of educators this has become a challenging task, most of all when $21^{\text {st }}$ century learners fill the classrooms. But these digital natives differ tremendously from those who started the millennium. These students want to be challenged, engaged and motivated through a learning process, which connects them to a different learning experience. This has become a challenging task for educators due to the student profile and characteristics. Although to achieve the learning outcomes necessary for the $21^{\text {st }}$ century, educators are adapting approaches suited for these learners, involving game theory, video games, and gamifying instruction. Two of these approaches are Gamification and Game-Based Learning (GBL). These two approaches have been widely used based on the theoretical approach towards game design and the opportunity they bring for the learner to be engaged and motivated throughout instruction. The following article provides a clear overview of both strategies, and how motivation is integrated with both. In addition it provides a clear description on planning effective instruction using aligned learning objectives, research and educational implications, and resources for the teaching and learning process using these approaches and strategies.
\end{abstract}

\section{Keywords}

education, gamification, game-based learning, education, game theory, instructional technologies

\section{Introduction}

According to Jerald (2009), technology has been transforming human life in one way or another for centuries. For example, the mechanization of agriculture transformed the American labor market in the first half of the $20^{\text {th }}$ century. But in the computer age, the pace of technological is continuously changing. Many experts say that since the 1970s, new technologies, combined with demographic, political, and economic trends, have altered Americans' work and social lives in ways that have significant consequences for today's young people. Those trends have prompted some education 
reformers to argue that the traditional curriculum is not enough: schools must provide students with a broader set of " $21^{\text {st }}$ century skills" to thrive in a rapidly evolving, technology-saturated world. On the other hand, the use of technology has been widely integrated in education this century. But in many cases the $21^{\text {st }}$ century learner hasn't been able to receive proper instruction due to unauthentic ways of content delivery and assessment using emergent technologies. Most of the time technology serves as a platform for linear, teacher-centered delivery of information and simple, computer-assisted ways of assessment that tend to address the lowest levels of cognition: remembering and, at its best, understanding (Anderson \& Krathwohl, 2001).

According to Blair (2012), "a dramatic shift is sweeping through our schools". Nowadays, everyone sees elementary students using cell phones, PreK and K students navigating an iPod or iPad better than adults, students in middle school with a strong audience following their blogs, tweets, or YouTube channel. What comes to the mind of the educator is that these learners are not the same from the first part of the $21^{\text {st }}$ century. They evolved, demanding more engaging learning strategies in order to gain access to new knowledge. Blair (2012) mentions that for these students, watching videos or images during class, playing an Internet multiplication game, or even taking turns at an interactive whiteboard is no longer enough. In order to move in that tide, educators are continuously seeking novel instructional approaches, and it is largely agreed that today's schools face major problems around student motivation and engagement (Lee \& Hammer, 2011). In order to work with this evolution of $21^{\text {st }}$ century learners, the approaches of Gamification and Game-Based Learning (GBL) appear to be the learning strategies much needed to engage and motivate the students. The use of these approaches as learning tools look promising due to characteristics of the $21^{\text {st }}$ century learner the fact that they reinforce not only knowledge but also important skills such as problem solving, collaboration, and communication. Games have remarkable motivational power; they utilize a number of mechanisms to encourage people to engage with them, often without any reward, just for the joy of playing and the possibility to win. Creating a highly engaging, full-blown instructional game however is difficult, time consuming, and costly (Kapp, 2012), while typically targeting only a single set of learning objectives as chosen by the game designer. In addition, their effective classroom adoption requires certain technical infrastructure and appropriate pedagogical integration. As opposed to using elaborate games requiring a large amount of design and development efforts, the "gamification" approach suggests using game thinking and game design elements to improve learners' engagement and motivation.

The following article presents how these two approaches are suited for the $21^{\text {st }}$ century learner. It shows the concept of Gamification and its application in education. In addition offers a wide view of GBL and some of it's uses. Finally, it provides resources used in different levels of education in order for the educator to adapt the learning experience based on its necessities and possible learning outcomes. 


\section{Discussion}

\subsection{The Concept of Gamification}

According to Werbach and Hunter (2012), Gamification is defined as the use of game elements and game design techniques in non-game contexts. It is based in the success of the gaming industry, social media, and decades of research in human psychology. Basically, any task, assignment, process or theoretical context can be gamified (Werbach \& Hunter, 2012). The main objective of Gamification is to increase the participation of a person during an activity and provide motivation by integrating game elements such as prizes or awards and leaderboards.

In order to have a clear understanding about this concept is important to break down the definition and take a closer looked at the components, cited in the work of Sailer, Hense, Mandl and Klevers (2013).

These components are: game, element, design, and non-game contexts.

Table 1. Gamification Definition Components

\begin{tabular}{ll}
\hline Concept & Definition \\
\hline Game & Implies the following situational components: a goal, which has to be achieved; \\
& limiting rules which determine how to reach the goal; a feedback system which \\
& provides information about progress towards the goal; and the fact that \\
& participation is voluntary. \\
& It helps distinguish the concept of Gamification from serious games. \\
Element & It refers to the use of game design instead of game-based technologies or practices \\
Design & of the wider game ecology. \\
Non-game contexts & Refers to the area of application, which is not limited to certain contexts. \\
\hline
\end{tabular}

\subsubsection{Game Elements and Components}

According to Sailer, Hense, Mandl and Klevers (2013), video games follow a design pattern, which integrate certain elements or components. This is crucial at the time of designing a game and it's essential towards the main objective of Gamification, which is motivation. Some of these components include: points, badges, leaderboards, progress bars/progression, performance graphs, quests, levels, avatars, social elements, and rewards/rewards system. They are defined as follows:

1. Points: Numeric accumulation based on certain activities.

2. Badges: Visual representation of achievements for the use has shown online.

3. Leader boards: How the players are ranked based on success.

4. Progress bards/Progression: Shows the status of a player.

5. Quests: Some of the tasks have to fulfill in a game.

6. Levels: A section or parts of the game.

7. Avatars: Visual representation of a player or alter ego. 
8. Social elements: Relationships with other user through the game.

9. Rewards/rewards system: System to motivate players that accomplish a quest.

All these elements have different purposes and can be adapted to basically any work, business or education related environment. According to Dickey (2005), every game integrates three basic elements: meta-centered activities, rewards, and progression. But is the element of "rewards" that call to the attention of the participant depending on the context. The work of Smith-Robbins (2011), suggests that three principal categories exist for "rewards" and include: leaders, prizes/awards, and achievements. The "leaders" are participants classified based on their game success. It's the same concept used in sports and most of the time incorporates a leader board. Another category is "prizes/awards", which promotes an additional commitment and engagement by the participant (Glover, Campbell, Latig, Norris, Toner, \& Tse, 2012).

Finally, "achievements" are publicly shown icons, or the so-called badges, in the participant online profile. They are perceived as the integration or combination of the previously mentioned reward categories. The integration and use of badges, each with a different meaning, has grown tremendously in part to the development of game consoles and online gaming.

\begin{tabular}{|c|c|c|c|c|c|c|c|c|c|c|}
\hline Users & & Badges & v & Problem & Solution & Idea & Question & Answer & Comment & Points \\
\hline 16 & $\begin{array}{l}\text { James Anderson Company Manager } \\
\text { jamesanderson@examplecompany.com }\end{array}$ & & & 10 & 10 & 10 & 10 & 10 & 10 & 10,000 \\
\hline 2 & $\begin{array}{l}\text { BrynnEvans Admin } \\
\text { brynnevans@examplecompany.com }\end{array}$ & & & 10 & 10 & 10 & 10 & 10 & 10 & 10,000 \\
\hline 3 & $\begin{array}{l}\text { Aaron Irizarry Admin } \\
\text { aaronirizarry@examplecompany,com }\end{array}$ & & & 10 & 10 & 10 & 10 & 10 & 10 & 10,000 \\
\hline 4 & $\begin{array}{l}\text { James Wilson } \\
\text { jameswilson@examplecompany.com }\end{array}$ & & & 10 & 10 & 10 & 10 & 10 & 10 & 10,000 \\
\hline 5 & $\begin{array}{l}\text { Grace } \mathrm{Ng} \\
\text { graceng@examplecompany.com }\end{array}$ & & & 10 & 10 & 10 & 10 & 10 & 10 & 10,000 \\
\hline 6 & $\begin{array}{l}\text { Ben Moskovits } \\
\text { benmoskovits@examplecompany.com }\end{array}$ & & & 10 & 10 & 10 & 10 & 10 & 10 & 10,000 \\
\hline 7 & $\begin{array}{l}\text { Adam Oykun } \\
\text { adamoykun@examplecompany.com }\end{array}$ & & & 10 & 10 & 10 & 10 & 10 & 10 & 10,000 \\
\hline 8 & $\begin{array}{l}\text { Mike Ball } \\
\text { mikeball@examplecompany.com }\end{array}$ & & & 10 & 10 & 10 & 10 & 10 & 10 & 10,000 \\
\hline 9 & $\begin{array}{l}\text { AdelleCharles } \\
\text { adellecharles@examplecompany.com }\end{array}$ & $P$ & & 10 & 10 & 10 & 10 & 10 & 10 & 10,000 \\
\hline 10 & $\begin{array}{l}\text { Tony Peterson } \\
\text { tonypeterson@examplecampany.com }\end{array}$ & D & & 10 & 10 & 10 & 10 & 10 & 10 & 10,000 \\
\hline
\end{tabular}

Figure 1. Example of Leaders, Prices/Awards, and Achievements

\subsubsection{Game Design and Non-Game Contexts}

Game design and non-game contexts are instrumental in Gamification and are an integral part of the definition provided by Werbach and Hunter (2012). Video games are design following a system; they are not only elements. They also fit an artistic purpose comprised with originality, in order to show creativity and not a copy of another game. By this means presenting originality and character at all times. The design needs to be balanced in order to let the "player" reflect on the game experience and continue the tasks. 
In addition to the game design, Gamification follows a vision of non-game contexts. By this means that the target objectives are not focused solely in having fun or enjoyment, both will be part of the experience (Webarch \& Hunter, 2012). In a recent study Pappas (2013) mentions that the use of game-like strategies make training for the work environment more interesting, gratifying, and applicable than other techniques.

\subsubsection{Uses in Gamification}

According to Figueroa (2015), plenty of uses have been given to Gamification previous to the education field. Some uses include: employee motivation, conceptualization of the concept of energy preservation, to beat and understand diseases, create healthy competition, to promote charitable donations, promote customer loyalty, education, language learning, among others. The following are two examples that present the concept of Gamification with diverse purposes:

1) U.S Army-America's Army: For many years the U.S. Army has been using games for training purposes. But, nowadays they are using Gamification, by integrating a gamifying experience called America's Army, with the final mission of recruiting people for their branch of the United States armed forces.

2) Chore Wars: One of the aspects of Gamification it that in order to promote motivation it promotes competition. But is not a competition that will finish in discord, is healthy competition to engage people in achieving an objective. This type of competition is presented thru Chore Wars, which is often used for employee motivation (Dale, 2014).

\subsubsection{Motivation and Gamification}

There are six principal perspectives in motivational research that has been linked to Gamification: Trait, Behavioristic Learning, Cognitive, Self-determination, Interest, and Emotion explained in the work of Sailer, Hense, Mandl and Kelvers (2013). Each perspective has its own characteristic, for example, the Trait perspective observes motives as individual characteristics and some of the important one that it presents include achievement, need for power, and affiliation (McClelland, 1961, 2009). On the other hand, Behavioristic Learning is seen as a result of previous experiences, including past positive or negative reinforcement, or stimulus-response bonds (Skinner, 1963). An application of these toward enhancing L2 and Gamification will be to use reflexive journals or sharing experiences thru the creation of an avatar. The Cognitive perspective perceives motivation as a means-ends analysis where is dependent of situation-specific goals, and expectancies regarding the outcome of the situation itself, expectancies of the consequences of the outcome, and the subjective value (Heckhausen, 1977; Heckhausen \& Heckhausen, 2008). Also the influence on the variables could differentiate a performance intrinsic motivation (Schunk, Pintrich, \& Meece, 2010). The perspective of Self-determination postulates the psychological needs for competence, autonomy, and social relatedness. The fulfillments of these needs are necessary in intrinsic motivation and can be extrinsically perceived by the fulfillment of the needs (Ryan \& Deci, 2000). On the other hand, Interest is seen by researchers as an affective and cognitive variable and evolves in content specific and 
interaction with the environment (Hidi, Renninger, \& Krapp, 2004). Finally, Emotion can be influenced by instructional strategies as it outlined by researchers as an emotional design of instruction, which works with motivational mechanisms (Astleitner, 2004). Below are some of these implications based on their perspective and adapted from the work of Sailer, Hense, Mandl and Kelvers (2013):

1) Trait: "Players with a strong achievement motive are likely to be motivated if Gamification emphasizes achievement, success and progress. Players with a strong power motive are likely to be motivated if Gamification emphasizes status, control and competition. Players with a strong affiliation motive are likely to be motivated if Gamification emphasizes membership".

2) Behavioristic learning: "Players are likely to be motivated if Gamification provides immediate feedback in form of positive and negative reinforcement. Players are likely to be motivated if Gamification offers rewards".

3) Cognitive: "Players are likely to be motivated if Gamification provides a clear and achievable goal. Players are likely to be motivated if Gamification highlights the resulting consequences of a goal. Players are likely to be motivated if Gamification emphasizes the importance of a persons' action within a given situation. Players are likely to be motivated if Gamification fosters mastery orientation regarding goals".

4) Self-determination: "Players are likely to be motivated if they experience the feeling of competence. Players are likely to be motivated if they experience the feeling of autonomy. Players are likely to be motivated if they experience the feeling of social relatedness".

5) Interest: "Players are likely to be motivated if Gamification meets the players' interests and sparks interest for the situational context. Players are likely to be motivated if Gamification enhances the feeling of flow by providing direct feedback. Players are likely to be motivated if Gamification enhances the feeling of flow by providing a clear goal. Players are likely to be motivated if Gamification enables the feeling of flow by adapting the level of difficulty to ones' individual skills and competences".

6) Emotion: "Players are likely to be motivated if Gamification decreases negative feelings like fear, envy, and anger. Players are likely to be motivated if Gamification increases positive feelings like sympathy emotion and pleasure".

\subsection{Gamification in Education}

As the $21^{\text {st }}$ century moves forward, and technology continues to be an integral part of it, new pedagogical strategies have appeared. These strategies are developed based on the needs, the environment, and competences of the $21^{\text {st }}$ century learner. This $21^{\text {st }}$ century learner is called "digital native". According to Prensky (2001), a digital native learns and processes information different. They are described as living lives immersed in technology, "surrounded by and using computers, videogames, digital music players, video cams, cell phones, and all the other toys and tools of the digital age" (Prensky, 2001). The digital native belongs to the Net-generation and in many cases is labeled as a "millennial" (Howe \& Strauss, 2000, 2003). According to Mongan-Rallis (2009), the digital native 
wants to be engaged by the instructor and expected to create and consume.

One of these new pedagogical strategies is Gamification. It is basically new to education and has adjusted rapidly to the profile of the $21^{\text {st }}$ century learner or digital native. According to Kingsley and Grabner-Hagen (2015), Gamification in education let the instructor gamify an activity or a certain literacy skill. It integrates game elements and rewards mechanisms as part of the lecture, while motivating and engaging the student, and promoting healthy competition. The students learn a concept and practice skills just like if they were playing in a game. This makes the educational experience challenging and fun (Vassileva, 2008) and at the same time motivates the learner to move forward. The objective for integrating Gamification towards education is to unchain a more attractive and effective learning experience for the student (Figueroa, 2015).

Nowadays, more educators are using Gamification as part of their teaching strategies. This is due in part to the recognizing that games designed in an effective form stimulate large gains in productivity and creativity. In addition, Gamification has been successful in non-traditional educational settings such as E-learning. Kaplan University embedded Gamification software to their LMS and ran a pilot project in one of its courses. The results included an improvement of $9 \%$ on the students' grades and a 16\% course completion improvement (NMC-Horizon Report, 2014). Another success story, presented in the work of Figueroa (2015), involves the Deloitte Leadership Academy. The academy was successful implementing game elements such as badges for the students participating in the curriculum based "missions" and completing the tasks. The students were able to share their badges on LinkedIn. Gamification in education offers the learners an opportunity to interact among themselves as it's implied in a social game. Another detail is that when people perceive any form of social presence they tend to respond in a natural way to feelings such as happiness, empathy, and frustration, or even follow social rules like taking turns (Fogg, 2002).

In order to have a successful Gamification teaching and learning experience, where the $21^{\text {st }}$ century learner becomes engaged and motivated, the educator needs to plan accordingly. This requires that every instructor follow the five-step model for educational gamification, which is presented in the work of Huang and Soman (2013).

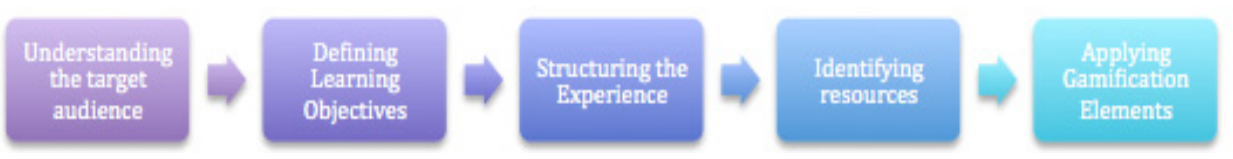

Figure 2. Educational Gamification Five Step Model

Each step of the model presented by Huang and Soman (2013) is described in the work of Figueroa (2015). It includes the following:

"Step 1: Understanding the Target Audience and the context, in this step the instructor needs to know who his or her students are. A combination of the target audience is necessary along with nalyzing the 
context to understand several key factors like group size, environment skills sequence, and length. Is in this step is where the pain points are exposed. Pain points are real problems, which make an entrepreneur look for solutions. In education there are somecommon pain points like: focus, motivation, skills, pride, learning environment and nature of the course, and physical, mental and emotional factors. By understanding these points the educator will be ready to determine the Gamification elements to implement".

"Step 2: Defining the Learning Objectives, is always necessary for a successful teaching and learning experience. The objectives need to have general instructional goals, specific learning goals, and behavioral goals. In order to have a successful learning experience thru Gamification the instructor needs to have the ability of combining and implementing the learning objectives".

"Step 3: Structuring the Experience, looks to break down the program and identify the main points. In this stage the instructor prepares the sequence and quantify what the student need to learn and achieve by the end of each stage. If students are staying behind, the instructor needs to re-think and provide a push for motivation in order for the student to complete the stage. The educator needs to move his educational program from simple to complex by starting with easier milestones so that the student stays engaged and motivated".

"Step 4: Identifying Resources, is shown at the moment the stages have been identified, the instructor will have complete assurance of which stage can or can't be gamified. The instructor needs to reflect in regards to several aspects that need to be considered. These are: tracking mechanisms, currency, levels, rules, and feedback. The image below presents these aspects along with definitions".

"Step 5: Applying Gamification Elements, in this step the educator decides which Gamification elements should be applied. The elements are divided in self and social. Self-elements most of the time uses badges, levels and time restrictions. They focus on making students compete with themselves and recognize self-achievement. Meanwhile, interactive competitions along with cooperation are seen as social-elements. Is with this type of element that students' achievements are made public and the students become part of a community".

After presenting the five-step model is important to reflect and envision the educational objectives in order to properly gamify instruction. The $21^{\text {st }}$ century learner will envision them as challenges and will be motivated to move from one level to another, or from one stage to another. This could become part of a learning outcome. The core of Gamification is motivation. In addition, if an instructor is willing to commit its teaching passion and follow the model, the learner will be immersed in an instructional scenario filled with plenty of creativity and healthy competition. This could include the integration of avatars, badges, leader boards, and progress charts, similar to the one they have in console games that will motivate and engage the digital native to achieve another educational task.

\subsection{Game Based Learning}

At this stage it's imperative to mention that nowadays computer games for entertainment had influenced the socio-cultural aspects of today's society. In addition, society has stereotype the players 
of these games labeling as "teenage boys" when the data tells a different story. Scholars such as Epper, Derryberry and Jackson (2012), mentioned that a study conducted by Newzoo and Humana Games in 2011 found that $47 \%$ of game players were women and $29 \%$ were over age 50.4 . The study also included that educational games were gaining prominence and media attention, which indicated a positive adoption towards Game-Based Learning (GBL). Supporting this statement was Johnson (2011), as he cited the 2011 NMC-Horizon Report, which indicated that GBL, already a pedagogical strategy suited for the $21^{\text {st }}$ century learner, was likely to become one of the mainstreams in the coming 2-3 years.

According to Perrotta Featherstone Aston and Houghton (2013), GBL refers to the use of video games to support teaching and learning. It is a natural evolution from traditional methods of teaching, which include static, non-interactive elements, such as textbooks, chalkboards, and lecturing at students rather than exploring with students. It's a form of experiential engagement in which people learn by trial and error, by role-playing and by treating a certain topic not as "content" but as a set of rules, or a system of choices and consequences. Games in education provide a vehicle by which students can explore, solve problems, attempt challenges, make decisions, and educational games contribute to learning broadly (Mead, 2011). GBL has shown to be an effective means of enhancing both learning motivation and academic performance (Chang, Wu, Weng, \& Sung, 2012; Virvou, Katsionis, \& Manos, 2005). GBL could be considered the "big brother" of Gamification in Education and Gameplay in Education.

One important aspect to consider is that GBL is a strategy that can adapt educational video games and leisure use video games, which the digital native plays a minimum of $3 \frac{1}{2}$ hours a week (Mongan-Rallis, 2009). This gives the learning process a certain type of flexibility because the teacher is able to implement video games played by the $21^{\text {st }}$ century on a daily basis as part of the instruction. This leads to different blended experiences during the process. In order to implement GBL, is necessary to understand the principles and mechanisms that support the strategy. Both concepts are mentioned in the work of Perrotta, Featherstone, Aston and Houghton (2013). Lastly, is necessary to for the educator in order to prepare develop a good learning and environment and achieve learning outcomes, to compare and contrast GBL and Gamification.

\subsubsection{Principles and Mechanisms of GBL}

In order to engage the $21^{\text {st }}$ century learner, the teaching and learning process needs to be precise. This digital native wants to learn and is eager to use video games and compete. In order to plan a proper curriculum and achieve successful learning outcomes with GBL, certain principles and mechanisms must be taken into consideration. The term "principles" imply underlying assumptions and concepts as explained by Perrotta, Featherstone, Aston and Houghton (2013). The following are the "principles" of GBL:

1) Intrinsic Motivation: "Gaming is intrinsically motivating because by and large it's a voluntary activity. Therefore, gaming for learning works best in the context of invitation and persuasion, rather than compulsion". 
2) Learning through enjoyment and fun: "Several authors suggest that games can be a vehicle for engaging students in a 'flow'. Flow is a state of consciousness during which an individual is in control of his actions and completely absorbed in the task at hand".

3) Authenticity: "Authenticity means a concern for the real nature of learning, which is supposedly different from the 'artificial' or decontextualized forms of learning that take place in schools. In the name of authenticity, contextual skills are prioritized over the abstract notions and facts valued in traditional instruction. Therefore, 'good' gaming reflects actual learning processes, which are always grounded in specific settings and practices. These can be actual professions, but also extravagant, fantastic roles and endeavors".

4) Self-reliance and autonomy: "Gaming encourages independent inquiry and exploration; interests and passions can branch off from the individual game, towards aspects of the 'ecosystem' that surrounds it. These aspects include technical and artistic skills like programming, writing, drawing, making music; but also the desire to find out more about certain topics, e.g., about science, history or mythology".

5) Experiential learning: "The notion of experiential learning is a very old and influential one in education, dating back to the seminal work of John Dewey. Many claim that gaming provides a cost effective alternative to learning by doing in real settings".

On the other hand the term, "mechanisms" is defined as the processes and dynamics which makes people understand how video games can, in theory, assist the pursuit of educational goals (Perrotta, Featherstone, Aston, \& Houghton, 2013). The following are the "mechanisms" of GBL:

1. Rules: "These rules can be more or less complex depending on the choices they elicit and the related consequences. For instance, rules can be simple and binary (if/then); or multifaceted and accommodating a broad range of decision making processes".

2. Clear but challenging goals: "The presence of clearly defined, demanding activities which, although might appear arbitrary and unnecessary, allow people to see the direct impact of their efforts".

3. Fictional setting or "fantasy" for compelling background: "This is an essential but easily misunderstood aspect of gaming". Notwithstanding the tendency to indulge in escapism and compensatory fantasies, classic studies on playing suggest that pretense can also be a deliberate and conscious strategy that assists learning. A consensual and transparent adherence to a fictional setting or role allows players to experiment with skills and identities without suffering the consequences of failure in real life.

1) Progressive difficulty levels, underpinned by understandable criteria for progression: "Over the years game developers have devised mechanisms for progression and 'levelling up' to a considerable degree of refinement. Not all of these mechanisms may be appropriate in an educational context, but they raise interesting questions for educators - not least the fact that players are allowed to tackle challenges and tests (like exams) as many times as necessary — and with no lasting consequences - in order to progress from one level to another".

2) Interaction and high degree of student control: "This mechanism is strongly related to the notion of 
'agency': the feeling of being in control of one's destiny through actions and choices. Most importantly, it concerns the certainty that effort and dedication will be acknowledged and rewarded".

3) A degree of uncertainty and unpredictability: "As long as it does not contradict point 5, a measured injection of uncertainty into tasks is consistent with many game developments tenets. For example, in the Quest schools students are not given assignments as such, but asked to choose between numbers of possible 'missions'. The scope and purpose of the missions become clear only when certain clues have been gathered and deciphered".

4) Immediate and constructive feedback: "One of the most powerful mechanisms of video games is the ability to provide feedback in real time, not only as evaluation, but more often as guidance to facilitate and correct performance. This is largely in line with the idea of formative assessment in education".

5) A social element that allows people to share experiences and build bonds: "As mentioned several times in this chapter, a game is not simply a product or tool, which may or may not have a relationship with learning. The ecosystem surrounding the game is just as important. In fact, it is probably even more relevant from an education perspective, because it provides players with a range of opportunities to share, interact and pursue interests and passions".

\subsubsection{Comparing and Contrasting Gamification in Education and GBL}

The $21^{\text {st }}$ century has provided educators with different approaches to work with the digital natives. Those approaches or learning strategies try to be suited to the $21^{\text {st }}$ century learner needs. Two of these learning strategies are GBL and Gamification. Both have been widely used interchangeably by instructors in K-12 and in Higher Education in order to transform social situation with game-like situations. Many people think that both approaches are the same, because they part from the word "game", but that's not the case. For example, Gamification involves applying game design thinking to non-game applications to make them more fun and engaging and it can be applied to any industry to create fun and engaging experiences. In education, Gamification is used to motivate and change the learner behavior using fun and engaging game-like environments. It encourages fun, intense focus, competitiveness, collaboration, retention, productivity, and creativity/exploration. The use of Gamification in education brings plenty of strengths to the teaching and learning process but it can also bring problems if not used properly. Some of the benefits that a $21^{\text {st }}$ century learner encounter in a gamified class include: fun and engaging classroom, a constant motivation for the student to complete the learning activities, promotes that the student becomes more focus and attentive to their learning, and promote healthy competition between peers. Some of the problems that an educator could encounter by gamifying a class include: predictable and boring gamification activities by the learners, not meaningful experiences for the learners, and not well-defined objectives.

On the other hand GBL is game-play with defined learning outcomes and with the idea to get students to play in order to fulfill a learning objective. According to Isaacs (2015), GBL relates to the use of games to enhance the learning experience. Educators have been using games in the classroom for years. Some of the benefits of using GBL with the $21^{\text {st }}$ century learner includes: using self-directed learning and 
promoting the students to become problem solvers, promote the game design thru the students, foster the learning of new modalities, and promote healthy competition between peers. Some of the problems that could arise include: the unfamiliarity of the instructor with the games or with GBL, not clear learning objectives, instruction becomes play time only, and technological infrastructure issues within the classroom setting.

The decision of which learning strategy or approach should be used with the $21^{\text {st }}$ century learners falls into the instructor. The following figure tends to portray the differences between Gamification and GBL.

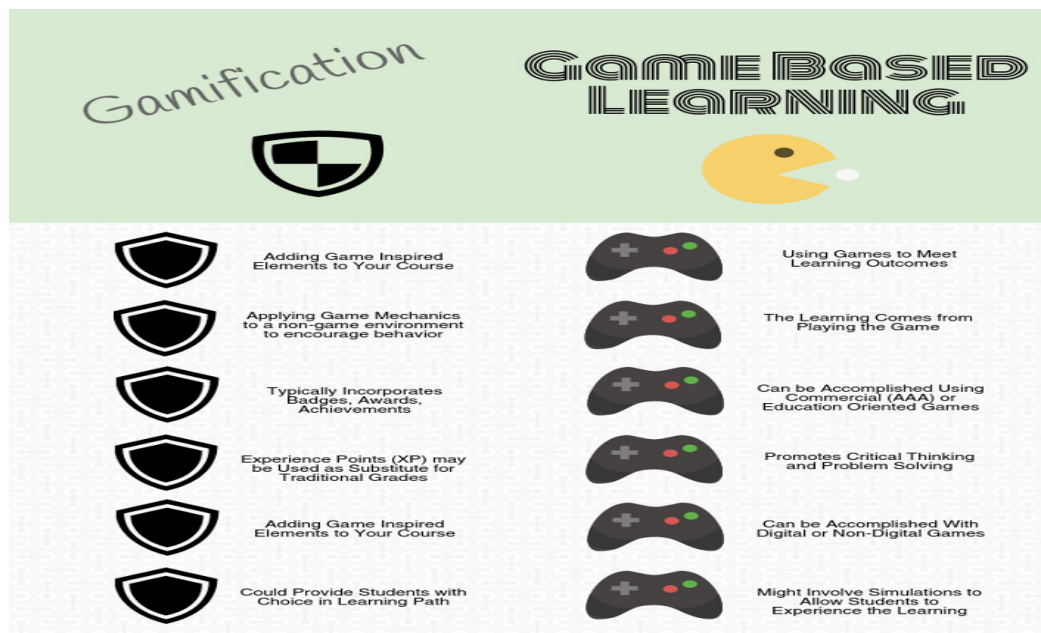

Figure 3. Differences between Gamification and GBL

\subsection{Educational Resources for Gamification and GBL}

Nowadays, there are plenty of accessible resources that can be implemented by instructors interested in using Gamification and GBL as parts of their strategies towards the $21^{\text {st }}$ century learner. Most are available in software, online, and mobile applications.

\subsubsection{Gamification Resources}

The following are a list of Gamification resources to implement in the teaching and learning experience and suited for the $21^{\text {st }}$ century learner:

1) Class Dojo: This main purpose of Class Dojo is to provide the instructor with a platform for student behavior management. It also helps in motivating elementary school learners thru strategies that combine avatars, points, and leader boards. Parents can be involved and connect with the educator. It track, shares, and evaluate student participation along with immediate feedback. It can be accessed via the Web interface or an Android or iOS app.

2) Duolingo: Is a Gamification language learning translation platform where users progress through several levels. It works for iPhone, iPod Touch, iPad, and Android. It covers the areas of speaking, listening, grammar and vocabulary necessary for L2 learning and content is always presented in whole sentences. The user can select between six languages including English, Spanish, Portuguese, Italian, German, and French. The feedback is immediate and the learner can easily track progress. Educators can 
use it as part of daily homework. It motivates student-driven work along with communication and collaboration.

3) Edmodo: It's a safe social networking platform for education with Gamification elements like badges and quests. It can be used as an extension of the classroom for all educational levels. In addition, it has an interface very similar to Facebook. Students can comment on posts, submit assignments, and track their progress. Educators can post polls, open discussion boards, design quizzes, and post assignment. It's a great motivating tool instruction because it promotes collaborative learning, teamwork, and parents have an account where they can receive feedback from the instructor. Edmodo works with any Web browser, iPad, iPhone, iPod Touch, Android, Windows Phone.

4) Socrative: Is a dynamic smart student response system that engages students via smart phones, tablets, and laptops, and empowers educators to formative and summative assessing their students. Students can answer questions forgetting about the stress involved in trials and errors, which lowers anxiety. It allows the users to import images to the question items and it feature Gamification strategies including live results, immediate feedback, and effortless data analysis.

\subsubsection{GBL Resources}

The following are a list of GBL resources that an instructor could be adapted in the classroom setting for the $21^{\text {st }}$ century learner:

1) World Peace Game: It's a hands-on political simulation that gives players the opportunity to explore the connectedness of the global community through the lens of the economic, social, and environmental crises and the imminent threat of war. The goal of the game is to extricate each country from dangerous circumstances and achieve global prosperity with the least amount of military intervention. As "nation teams", students will gain greater understanding of the critical impact of information and how it is used. 2) Minecraft-Edu: Let teachers quickly host servers and build custom maps with integrated content as well as create and administer assignments and lessons. There is also a useful set of classroom management tools that make it easy to define player abilities and items; to freeze, mute, and teleport students; and to create specific building areas with player permissions allowing for different lessons or projects on one map and preventing participants from angering or getting irritated during the video game or in other word "griefing".

1) Ten Frame Game: Online educational game suited for young learners. The objective is to have fun while learners understand the concept of value.

2) $3^{\text {rd }}$ World Farmer: It's a browser simulation game that let the advanced learner experience some of the hardships of farming in $3^{\text {rd }}$ world country.

\subsection{Conclusion}

In conclusion, Gamification and GBL are two learning approaches that become excellent strategies for the $21^{\text {st }}$ century learner. The promote student engagement along with novel techniques thanks in part to the gaming industry. It's difficult to create games or gamify instruction without proper understanding and knowledge of the approaches. In addition, extrinsic and intrinsic motivation of the $21^{\text {st }}$ century learner is 
something that needs to be taken into account at the moment of designing new curriculum using any of these approaches. There is still plenty of research that needs to be done in regards to the digital native, the approaches, and the teaching and learning experiences.

\section{References}

Anderson, L. W., \& Krathwohl, D. R. (2001). A Taxonomy of Learning, Teaching, and Assessment: A revision of Bloom's taxonomy of educational objectives. New York: Longman.

Astleitner, H. (2000). Designing emotionally sound instruction: The FEASP approach. Instructional Science, 28, 169-198. https://doi.org/10.1023/A:1003893915778

Blair, N. (2012). Technology Integration for the New 21st Century Learner, 8-13. Principal. January/February.

Chang, K.-E., Wu, L.-J., Weng, S.-E., \& Sung, Y.-T. (2012 ). Embedding game-based problem-solving phase into problem-posing system for mathematics learning. Computers \& Education, 58(2), 775-786. https://doi.org/10.1016/j.compedu.2011.10.002

Dickey, M. D. (2005). Engaging by design: How engagement strategies in popular computer and video games can inform instructional design. Education Training Research and Development, 53(2), 67-83. https://doi.org/10.1007/BF02504866

Epper, R., Derryberry, S., \& Jackson, S. (2012). Game-based Learning (pp. 1-11). Research Bulletin. August.

Figueroa, J. F. (2015). Using Gamification to Enhance Second Language Learning. Digital Education Review, 27, 32-54.

Fogg, B. J. (2002). Persuasive technology: Using computers to change what we think and do. Ubiquity, December. https://doi.org/10.1145/764008.763957

Glover, I., Campbell, A., Latif, F., Norris, L., Toner, J., \& Tse, C. (2012). A Tale of One City: Intrainstitutional Variations in Migrating VLE Platform. Research In Learning Technology, 20. https://doi.org/10.3402/rlt.v20i0.19190

Hidi, S., Renninger, K. A., \& Krapp, A. (2004). Interest, a Motivational Variable That Combines Affective and Cognitive Functioning. In D. Y. Dai, \& R. J. Sternberg (Eds.), Motivation, emotion and cognition: Integrative perspectives on intellectual functioning and development (pp. 89-115). Erlbaum, Mahwah.

Howe, N., \& Strauss, W. (2000). Millennials Rising: The Next Great Generation. New York: Vintage.

Howe, N., \& Strauss, W. (2003). Millennials go to College. American Association of Collegiate Registrars and Admissions Officers.

Huang Hsin Yuan, W., \& Soman, D. (2013). A Practitioner's Guide to Gamification of Education.Research Report Series: Behavioral Economics in Action. University of Toronto-Rotman School of Management.

Isaacs, S. (2015). The Difference Between Gamification and Game-based Learning. ASCD in Service, Published by SCHOLINK INC. 


\section{January(15).}

Jerald, C. (2009). Defining a 21st century education. The Center for Public Education.

Kapp, K. M. (2012). The Gamification of Learning and Instruction. San Francisco, California, USA: Pfeiffer.

Kingsley, T., \& Grabner-Hagen, M. (2015). Gamification questing to integrate context, knowledge, literacy, and 21st century learning. Journal of Adolescents \& Adult Literacy, 59(1), 51-61. https://doi.org/10.1002/jaal.426

Lee, J. J., \& Hammer, J. (2011). Gamification in education: What, how, why bother? Academic Exchange Quarterl, 15(2), 1-5.

McClelland, D. C. (1961). The Achieving Society. Princeton, NJ. https://doi.org/10.1037/14359-000

McClelland, D. C. (2009). Human Motivation. Cambridge University Press: Cambridge.

Mead, K. (2011). Game-based Learning and Intrinsic Motivation. California State University at Fullerton class paper for IDT 520, Section 09, April 15.

Mongan-Rallis, H. (2009). Digital Natives \& Digital Immigrants: Exploring the Intergenerational Digital Divide. Presentation for Central High School In-service, March 20th.

New Media Consortium. (2014). Horizon Report on Technology and Higher Education. Retrieved March 3, 2015, from http://www.nmc.org/publication/nmc horizon report 2014 higher education edition

Pappas, C. (2013). Gamify the Classroom. Retrieved February 12, 2015, from http://www.elearningindustry.com/gamify-the-classroom

Perrotta, C., Featherstone, G., Aston, H., \& Houghton, E. (2013). Game-based learning: Latest evidence and future directions. Berkshire, UK: National Foundation for Educational Research.

Prensky, M. (2001). Digital Game-Based Learning. McGraw-Hill, NewYork.

Ryan, R. M., \& Deci, E. L. (2000). Self-determination theory and the facilitation of intrinsic motivation, social development, and well being. American Psychologist, 55(1), 68-78. https://doi.org/10.1037/0003-066X.55.1.68

Sailer, M., Hense, J., Mandl, H., \& Klevers, M. (2013). Phsycological Perspectives on Motivation through Gamification. Interaction Design and Architecture(s) Journal-IxD\&A, 19, 28-37.

Schunk, D. H., Pintrich, P. R., \& Meece, J. L. (2010). Motivation in education: Theory, research, and Applications. Pearson: Upper Saddle River.

Skinner, B. F. (1963). Operant Behavior. American Psychologist, 18(8), 503-515. https://doi.org/10.1037/h0045185

Smith-Robbins, S. (2011). "This Game Sucks": How to Improve the Gamification of Education. Educause Review, 46(1), 58-59.

Vassileva, J. (2008). Toward social learning environments. IEEE Transactions on Learning Technologies, 1(4), 199-213. https://doi.org/10.1109/TLT.2009.4

Virvou, M., Katsionis, G., \& Manos, K. (2005). Combining software games with education: Evaluation of its educational effectiveness. Journal of Educational Technology \& Society, 8(2), 54-65. 
Werbach, K., \& Hunter, D. (2012). For the Win: How game thinking can revolutionize your business. Wharton Digital. 